\title{
ОСОБЕННОСТИ ЮРИДИЧЕСКОЙ ОТВЕТСТВЕННОСТИ БАНКОВ И ИНЫХ КРЕДИТНЫХ ОРГАНИЗАЦИЙ В ИСПОЛНИТЕЛЬНОМ ПРОИЗВОДСТВЕ
}

Аннотация: в исполнительном производстве банк или иная кредитная организация чаще всего выступают в качестве взыскателя, должника, лица, осуществляющего отдельные исполнительные действия. В качестве взыскателя банк может быть привлечен к гражданско-правовой ответственности по ст. 1102 ГК за неосновательное обогащение и к административной - по 4. $3 \mathrm{~cm} .17 .14$ КоАП. Как к должнику, за неисполнение требований исполнительных документов, к банку применяется ответственность в виде исполнительского сбора, а также административная ответственность по ч. $1 \mathrm{~cm} .17 .14, \mathrm{~cm} .17 .15$ КоАП и отдельным статьям гл. 19 КоАП. Судебным приставам-исполнителям предпочтительнее использовать положения ст. $17.14 \mathrm{u}$ 17.15, так как производство по ним осуществляется должностными лицами ФССП и санкции здесь гораздо выше предусмотренных статьями гл. 19 КоАП. Особое внимание законодательство уделяет ответственности банков за невыполнение своих обязательств по обращению взыскания на денежные средства должника, находящиеся на счетах. $4.2 \mathrm{~cm} .17 .14$ КоАП устанавливает довольно серьезные санкции за подобные правонарушения. Однако анализ статистики и судебной практики показал, что эта статья практически не действует. Причинами такого положения являются: несоблюдение судебными приставами-исполнителями норм процессуального законодательства, законодательства об административных правонарушениях, об исполнительном производстве, невыполнение требований о порядке привлечения к административной ответственности, к составлению протоколов об административных правонарушениях и др. ФССП следует разработать подробные рекомендации по применению $4.2 \mathrm{~cm}$. 17.14 КоАП, совершенствовать профессиональные навыки своих сотрудников в области административного и процессуального законодательства. Также за подобные правонарушения банки могут быть привлечены к процессуальной по сm. 119 АПК и cm. 105 ГПК (судебные штрафы) и гражданско-правовой ответственности по ст. 1064 ГК (компенсация вреда). Однако эффрективность такой ответственности значительно уступает административной, особенно в части размера наказания.

Ключевые слова: банк, кредитная организация, исполнительное производство, взыскатель, должник, осуществление исполнительных действий, гражданско-правовая ответственность, административная ответственность, процессуальная ответственность, судебная практика. DOI: 10.7256/1994-1471.2014.2.9299

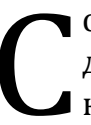
овременное законодательство отводит довольно заметную роль банкам и иным кредитным организациям при осуществлении исполнительного производства. Это связано, во-первых, с тем, что и граждане и организации имеют счета в банках, на которые возможно обратить взыскание по исполнительным документам. Во-вторых, в банках же могут храниться и ценности, являющиеся объектом взыскания. В-третьих, банк вправе осуществлять выпуск, покупку, продажу, учет, хранение и иные операции с ценными бумагами, выполняющими функции платежного документа, с ценными бумагами, подтверждающими привлечение денежных средств во вклады и на банковские счета, с иными ценными бумагами, осуществление операций с которыми не требует получения специальной лицензии в соответствии с федеральными законами, а также вправе осуществлять доверительное управление указанными ценными бумагами по договору с физическими и юридическими лицами. Кредитная организация имеет право осу-

(C) Воронов Евгений Николаевич

* К Кандидат юридических наук, доцент кафедры трудового права, гражданского и арбитражного процесса Юго-Западного государственного университета

[envoronov@yandex.ru]

305040, Россия, г. Курск, ул. 50 лет Октября, д. 94. 
ществлять профессиональную деятельность на рынке ценных бумаг в соответствии с федеральными законами ${ }^{1}$. В банке также можно получить информацию о наличии денежных средств, ценных бумаг и иных ценностей, принадлежащих должнику.

Наконец банки и кредитные организации сами являются активными участниками гражданского оборота, как в качестве кредиторов физических и юридических лиц, так и в качестве субъектов, осуществляющих заем. К тому же, банки и иные кредитные организации могут выполнять и иные виды деятельности, например, выдачу поручительств за третьих лиц, предусматривающих исполнение обязательств в денежной форме; приобретение права требования от третьих лиц исполнения обязательств в денежной форме; доверительное управление денежными средствами и иным имуществом по договору с физическими и юридическими лицами; осуществление операций с драгоценными металлами и драгоценными камнями в соответствии с законодательством Российской Федерации; предоставление в аренду физическим и юридическим лицам специальных помещений или находящихся в них сейфов для хранения документов и ценностей и др. ${ }^{2}$.

Банк или иная кредитная организация могут выступать в исполнительном производстве в качестве особого субъекта, уполномоченного осуществлять определенные исполнительные действия. В соответствии со ст. 7 ФЗ «Об исполнительном производстве», банки исполняют требования, содержащиеся в судебных актах, актах других органов и должностных лиц ${ }^{3}$. Также банки обязаны выполнять отдельные поручения судебного пристава-исполнителя, например, согласно ч. 3 ст. 72 (Порядок обращения взыскания на денежные средства должника при исчислении долга в иностранной валюте) указанного Закона, если денежные средства должника находятся на счетах и во вкладах в банках и иных кредитных организациях, которым в соответствии с лицензией на осуществление банковских операций не предоставлено право осуществлять куплю-продажу иностранной валюты, то судебный пристав-исполнитель своим постановлением обязывает банк или иную кредитную организацию перечислить

\footnotetext{
1 Федеральный закон от 2 декабря 1990 г. № 395-Ф3 «О банках и банковской деятельности», Ст. 6// Собрание законодательства РФ. 1996. № 6. Ст. 492.

2 См.: Там же. Ст. 5.

Федеральный закон от 2 октября 2007 г. № 229-Ф3 «Об исполнительном производстве» // Российская газета. 2007. 6 октября.
}

указанные денежные средства в банк, имеющий такое право.

Таким образом, банк в исполнительном производстве выступает в качестве взыскателя, должника, субъекта, осуществляющего отдельные исполнительные действия и некоторых других субъектов (например, участника рынка ценных бумаг, хранителя имущества и др.). Для всех указанных субъектов в случае нарушения ими законодательства об исполнительном производстве предусматриваются определенные виды ответственности.

Ответственность взыскателя в исполнительном производстве случается редко, поэтому данный вопрос еще не решен окончательно в юридической науке и практике. Думаем, что в отдельных ситуациях взыскатель может быть привлечен к гражданско-правовой и административной ответственности. Например, когда он при принудительном исполнении исполнительного документа получил имущества больше, чем было присуждено на основании исполнительного документа. Эту ситуацию можно квалифицировать как неосновательное обогащение. Согласно ст. 1102 ГК РФ, лицо, которое без установленных законом, иными правовыми актами или сделкой оснований приобрело или сберегло имущество (приобретатель) за счет другого лица (потерпевшего), обязано возвратить последнему неосновательно приобретенное или сбереженное имущество (неосновательное обогащение), за исключением случаев, предусмотренных ст. 1109 ГК РФ 4 . К административной ответственности банк как взыскатель может быть привлечен по ч. 3 ст. 17.14 КоАП РФ: «нарушение лицом, не являющимся должником, законодательства об исполнительном производстве» в части, касающейся невыполнении законных требований судебного пристава-исполнителя ${ }^{5}$.

В качестве должников для банков и иных кредитных организаций может применяться специфическая ответственность, предусмотренная ФЗ «Об исполнительном производстве». Так, согласно ст. 112 этого закона, с банка может быть взыскан исполнительский сбор. Это денежное взыскание, налагаемое на должника в случае неисполнения им исполнительного документа в срок, установленный для добровольного исполнения исполнительного документа, а также в случае 4 Гражданский кодекс Российской Федерации (часть
вторая) от 26 января 1996 г. № 14-ФЗ// Собрание зако-
нодательства РФ. 1996. № 5. Ст. 410.

Кодекс Российской Федерации об административных правонарушениях от 30 декабря 2001 г. № 195-Ф3 // Собрание законодательства РФ. 2002. № 1 (ч. 1). Ст. 1. 
неисполнения им исполнительного документа, подлежащего немедленному исполнению, в течение суток с момента получения копии постановления судебного пристава-исполнителя о возбуждении исполнительного производства. Исполнительский сбор зачисляется в федеральный бюджет. Устанавливается исполнительский сбор судебным приставом-исполнителем по истечении, указанного выше, срока, если должник не представил судебному приставу-исполнителю доказательств того, что исполнение было невозможным вследствие непреодолимой силы, то есть чрезвычайных и непредотвратимых при данных условиях обстоятельств. Постановление судебного пристава-исполнителя о взыскании исполнительского сбора утверждается старшим судебным приставом.

Размер исполнительского сбора составляет семь процентов от подлежащей взысканию суммы или стоимости взыскиваемого имущества. Однако для организаций он должен быть не менее пяти тысяч рублей. Так вступившим в законную силу решением Арбитражного суда Владимирской области по делу № А11-9761/2009 удовлетворено исковое требование общества с ограниченной ответственностью «Магазин «Авто-Холд» о взыскании с общества «Владимирский промышленный банк» действительной стоимости доли в сумме 29157844 руб. 50 коп. На основании исполнительного листа, выданного 3 февраля 2010 г., возбуждено исполнительное производство № 17/2/1805/5/2010. Поскольку общество «Владимирский промышленный банк» требования исполнительного документа в установленный срок в добровольном порядке не исполнило, судебный пристав-исполнитель 27 февраля 2010 г. вынес постановление о взыскании с общества «Владимирский промышленный банк» исполнительского сбора в размере 2041049 руб. 11 коп. $^{6}$

В случае неисполнения исполнительного документа неимущественного характера исполнительский сбор с должника-организации устанавливается также в размере пяти тысяч рублей. Исполнительский сбор за неуплату периодических платежей исчисляется и взыскивается с суммы каждой задолженности в отдельности.

Считаем также, что банк или иная кредитная организация как должники могут быть привлечены и к административной ответственности. Прежде всего, в данном случае может быть применена ч. 1 ст. 17.14 КоАП РФ (Нарушение должником законодательства об

6 Определение ВАС РФ от 22 марта 2012 г. № ВАС2858/12 по делу № А11-8516/2010// СПС КонсультантПлюс. исполнительном производстве, выразившееся в невыполнении законных требований судебного пристава-исполнителя). Однако КоАП РФ предусматривает и иные составы, по которым предусмотрена ответственность должника в исполнительном производстве. К ним, в частности, относятся: ст. 17.8 (Воспрепятствование законной деятельности судебного пристава), ч. 1 ст. 19.4 (Неповиновение законному распоряжению должностного лица органа, осуществляющего государственный надзор (контроль)), ч. 1 ст. 19.5 (Невыполнение в срок законного предписания (постановления, представления, решения) органа (должностного лица), осуществляющего государственный надзор (контроль)), ст. 19.6 (Непринятие мер по устранению причин и условий, способствовавших совершению административного правонарушения), ст. 19.7 (Непредставление сведений (информации)).

Использование положений гл. 19 КоАП РФ в исполнительном производстве усложняется необходимостью обращения в суд, так как судебные приставы-исполнители по этим составам вправе составлять только протоколы, тогда как по ч. 1 ст. 17.14 постановления могут выноситься непосредственно должностными лицами ФССП РФ, к тому же ст. 17.14 устанавливает более жесткие меры наказания. Например, санкция ст. 19.7 предусматривает наложение административного штрафа на граждан в размере от трехсот до пятисот рублей; на должностных лиц - от одной тысячи до двух тысяч рублей или дисквалификацию на срок до трех лет; на юридических лиц от десяти тысяч до двадцати тысяч рублей, ч. 1 ст. 17.14 КоАП РФ предполагает наложение административного штрафа на граждан в размере от одной тысячи до двух тысяч пятисот рублей; на должностных лиц - от десяти тысяч до двадцати тысяч рублей; на юридических лиц - от тридцати тысяч до ста тысяч рублей, что повышает эффективность воздействия на нарушителей законодательства об исполнительном производстве.

Как уже отмечалось выше, банк или иная кредитная организация могут выступать в исполнительном производстве в качестве особого субъекта, уполномоченного осуществлять определенные исполнительные действия. Законодатель уделяет особое внимание привлечению к ответственности банков за невыполнение своих обязательств по обращению взыскания на денежные средства должника, находящиеся на счетах. Согласно ст. 114. Ф3 «Об исполнительном производстве», в случае неисполнения в установленный указанным Законом срок исполнительного документа, содержащего требования о взыскании денежных 
средств с должника, банком или иной кредитной организацией, осуществляющими обслуживание счетов должника, при наличии денежных средств на указанных счетах судебный пристав-исполнитель составляет протокол об административном правонарушении в порядке, установленном ст. 28.2 КоАП РФ. Копия протокола вручается представителю банка или иной кредитной организации.

После составления протокола судебный пристав-исполнитель направляет в арбитражный суд по месту нахождения банка или иной кредитной организации подписанное им и заверенное печатью (штампом) подразделения судебных приставов заявление о привлечении банка или иной кредитной организации кадминистративной ответственности. В заявлении указываются: 1) наименование арбитражного суда, в который подается заявление; 2) наименование и адрес подразделения судебных приставов; 3) наименование и адрес банка или иной кредитной организации, в отношении которых составлен протокол об административном правонарушении; 4) дата и место совершения действий, послуживших основанием для составления протокола об административном правонарушении; 5) должность, фамилия и инициалы судебного пристава-исполнителя, составившего протокол об административном правонарушении; 6) требование о привлечении банка или иной кредитной организации к административной ответственности за совершение административного правонарушения, предусмотренного ч. 2 ст. 17.14 КоАП РФ (Hеисполнение банком или иной кредитной организацией содержащегося в исполнительном документе требования о взыскании денежных средств с должника); 7) иные необходимые сведения (номера телефонов, факсов, адреса электронной почты и другие); 8) перечень прилагаемых к заявлению документов.

Копии заявления и прилагаемых к нему документов направляются в банк или иную кредитную организацию, в отношении которых составлен протокол об административном правонарушении. К подаваемому в суд заявлению прилагаются протокол об административном правонарушении и прилагаемые к протоколу документы, а также уведомление о вручении или иной документ, подтверждающие направление копий заявления и прилагаемых к нему документов в банк или иную кредитную организацию, в отношении которых составлен протокол об административном правонарушении.

В соответствии со ст. 8 ФЗ «Об исполнительном производстве», исполнительный документ о взыскании денежных средств или об их аресте может быть направлен в банк или иную кредитную организацию непосредственно взыскателем. В этом случае, если банк не исполняет требования исполнительного документа, взыскатель может обратиться с заявлением в соответствующее подразделение ФССП РФ о привлечении банка к административной ответственности.

Как видим, законодательство довольно подробно регламентирует порядок привлечения банков и иных кредитных организаций к административной ответственности за правонарушения, предусмотренные ч. 2 ст. 17.14 КоАП РФ. К тому же, в этой статье предусмотрена довольно серьезная санкция - половина от денежной суммы, подлежащей взысканию с должника, но не более одного миллиона рублей, что дает повод говорить о хороших перспективах эффективности ее использования и достижении целей превенции в совершении подобных правонарушений. Однако практика применения ч. 2 ст. 17.14 складывается весьма неоднозначно.

Следует отметить, что из 37 возбужденных по ч. 2 ст. 17.14 КоАП РФ дел об административных правонарушениях в 2011 г. положительное решение арбитражного суда было вынесено только по двум, в 2012 г. из 28 - по четырем ${ }^{7}$. Судебная практика выявляет целый ряд недостатков в деятельности должностных лиц ФССП РФ по привлечению к административной ответственности банков, многие из которых являются типичными для всей административной практики судебных приставовисполнителей, а именно: несоблюдение норм процессуального законодательства, законодательства об административных правонарушениях, об исполнительном производстве, невыполнение требований о порядке привлечения к административной ответственности, к составлению протоколов об административных правонарушениях и др.

26 декабря 2011 г. судебным приставом-исполнителем Волжского районного отдела судебных приставов г. Саратова УФССП по Саратовской области был составлен протокол об административном правонарушении по ч. 2 ст. 17.14 КоАП РФ в отсутствие законного представителя ответчика - Саратовского филиала ЗАО коммерческого банка «РОСЭНЕРГОБАНК», г. Саратов ${ }^{8}$. В п. 17 Постановления Пленума ВАС РФ от 27 янва-

\footnotetext{
Ведомственная статистическая отчетность Федеральной службы судебных приставов за 2011 г; Ведомственная статистическая отчетность Федеральной службы судебных приставов за 2012 г. //http://www. fssprus.ru/statistics/ (последнее посещение - 28.07.2013).

8 Постановление ФАС Поволжского округа от 31 июля 2012 г. по делу № А57-1692/2012 //СПС КонсультантПлюс.
} 
ря 2003 г. указывается, что положения ст. 28.2 КоАП РФ, регламентирующие порядок составления протокола об административном правонарушении, представляют ряд гарантий защиты прав лицам, в отношении которых возбуждено дело об административном правонарушении. В частности, в протоколе отражается объяснение физического лица или законного представителя юридического лица по поводу вменяемого правонарушения; при составлении протокола названным лицам разъясняются их права и обязанности, о чем надлежит сделать запись в протоколе; указанные лица вправе представить объяснения и замечания по содержанию протокола, которые к нему прилагаются9. В итоге заявление судебного пристава-исполнителя о привлечении банка к административной ответственности судами первой, апелляционной и кассационной инстанции было отменено.

В данном случае мы видим, что судебный пристав-исполнитель слабо ориентируется в законодательстве об административных правонарушениях. Этот вывод подтверждается анализом практики применения ч.ч. 2 и 2.1 ст. 17.14 КоАП РФ, проведенным в 2011 г. службой судебных приставов, в котором указывается, что «основной причиной отказа арбитражными судами в удовлетворении заявлений судебных приставов-исполнителей о привлечении банков и иных кредитных организаций к административной ответственности по делам данной категории является слабое знание судебными приставами-исполнителями административного законодательства, норм АПК РФ и руководящих разъяснений ВАС РФ по вопросам, возникающим в правоприменительной практике» ${ }^{10}$. Судебный пристав-исполнитель обязан составлять протокол об административном правонарушении только в присутствии лица, в отношении которого ведется производство по делу об административном правонарушении, либо законного представителя данного лица. В протоколе также должны содержаться сведения о лице, привлекаемом к административной ответственности.

14 апреля 2011 г. в отношении филиала Коммерческого банка «Юниаструм банк» (000) в г. Магадане судебным приставом-исполнителем Межрайонного отдела судебных приставов по

Постановления Пленума ВАС РФ от 27.01.2003 № 2 «О некоторых вопросах, связанных с введением в действие Кодекса Российской Федерации об административных правонарушениях» // Вестник ВАС РФ. 2003. № 3.

10 Письмо Федеральной службы судебных приставов от 18 марта 2011 г. № 12/04-5833-BВ «О практике применения судебными приставами-исполнителями части 2 и части 2.1 статьи 17.14 КоАП РФ» // http://www.referent. ru/1/181687 (последнее посещение - 20.07.2013). исполнению особо сложных исполнительных производств УФССП России по Магаданской области был составлен протокол № 38 об административном правонарушении, предусмотренном ч. 2 ст. 17.14 КоАП РФ.

Из протокола усматривается, что он составлен в отношении ФКБ «Юниаструм банк» (000), то есть филиала Банка в г. Магадане, что является нарушением положений п. 3 ст. 55 ГК РФ, поскольку представительства и филиалы не являются юридическими лицами, и соответственно, не могут быть субъектами административного правонарушения. Кроме этого, названный протокол составлен в присутствии главного бухгалтера филиала КБ «Юниаструм банк» (000) в г. Магадане Белозеровой И.А. по доверенности, выданной на представление интересов филиала. В протоколе также изложены сведения не о лице, привлекаемом к административной ответственности - Коммерческом банке «Юниаструм банк» (000), а о его представителе Белозеровой И.А., в частности о регистрации, месте жительства, месте нахождения, семейном положении, месте работы, размере зарплаты, о не привлечении ранее к административной ответственности. Из названного протокола также усматривается, что юридическое лицо - КБ «Юниаструм банк» (ООО) о времени и месте составления протокола об административном правонарушении не извещалось, при составлении протокола законный представитель юридического лица не присутствовал ${ }^{11}$.

Анализ судебной практики показывает также, что протоколы об административных правонарушениях, предусмотренных ч. 2 ст. 17.14 должностными лицами ФССП РФ составляются в отношении ненадлежащих лиц ${ }^{12}$.

Не редко причиной отказа в привлечении банка к административной ответственности за неисполнение содержащегося в исполнительном документе требования о взыскании денежных средств с должника становится несоблюдение судебным приставом-исполнителем порядка, предусмотренного ст. 70 ФЗ «Об исполнительном производстве». Так, судебный пристав-исполнитель в рамках исполнительного производства № 92/415/6319/43/2009, установив у должника 000 «Спецавтоматика» наличие расчетного счета, открытого в ОАО «АКБ «БТА-КАЗАНЬ», вынес 2 июня 2010 г. постановление об обращении взыскания на денежные средства, которое направил в Банк.

\footnotetext{
11 Постановление Шестого арбитражного апелляционного суда от 10 августа 2011 г. № 06АП-2889/2011// СПС КонсультантПлюс.

12 Постановление ФАС Северо-Кавказского округа от 9 сентября 2008 г. по делу № А18-444/2008// СПС КонсультантПлюс.
} 
Банком в адрес судебного пристава-исполнителя было направлено уведомление о возврате данного постановления без исполнения в связи с отсутствием денежных средств на расчетном счете должника и наложенным ранее арестом Межрайонной инспекцией Федеральной налоговой службы по Республике Татарстан. Считая, что в действиях Банка содержится состав административного правонарушения, ответственность за которое установлена ч. 2 ст. 17.14 КоАП РФ, судебный пристав-исполнитель составил протокол об административном правонарушении и направил соответствующее заявлений в Арбитражный суд Республики Татарстан.

Суд первой инстанции в своем решении, ссылаясь на ч.ч. 1 и 3 ст. 12, ч. 2 ст. 70 ФЗ «Об исполнительном производстве» указал, что, исходя из буквального толкования указанных норм для исполнения требований исполнительного документа, судебный пристав должен направить два документа, а именно: постановление о возбуждении исполнительного производства с приложением копии исполнительного документа, на основании которого возбуждено данное исполнительное производство. Судебный пристав-исполнитель направил в Банк только постановление об обращении взыскания на денежные средства. Постановлением Арбитражного суда Республики Татарстан заявление судебного пристава-исполнителя было отклонено, суд кассационной инстанции согласился с этим решением ${ }^{13}$. Аналогичная практика складывается и в других судах ${ }^{14}$.

Видя проблемы в применении положений ч. 2 ст. 17.14 КоАП РФ, некоторые подразделения ФССП РФ стали использовать при выявлении указанных правонарушений иных положений КоАП РФ. В рамках исполнительного производства № 6724/10/01/77 судебным приставом-исполнителем Тверского районного отдела судебных приставов УФССП по Москве было вынесено постановление об обращении взыскания на денежные средства 000 «Вебдивижн», находящиеся на счете в АКБ «РОСЕВРОБАНК» (ОАО). Банк вернул постановление без исполнения. Заместитель старшего судебного пристава Тверского РОССП УФССП по г. Москве усмотрел в действиях Банка признаки административного правонарушения, предусмотрен-

13 Постановление ФАС Поволжского округа от 21 декабря 2010 г. по делу № А65-16539/2010 // СПС КонсультантПлюс.

14 См., например: Постановление Тринадцатого арбитражного апелляционного суда от 3 ноября 2011 г. по делу № А21-4801/2011; Постановление ФАС СевероЗападного округа от 2 октября 2008 г. по делу № А421892/2008 // СПС КонсультантПлюс. ного ч. 3 ст. 17.14 КоАП РФ и вынес соответствующее постановление ${ }^{15}$, хотя данное деяние квалифицируется по ч. 2, указанной статьи, а дело об административном правонарушении должно рассматриваться арбитражным судом.

По сути, указанные факты говорят о том, что ч. 2 ст. 17.14 КоАП РФ практически не действует, из-за ошибок судебных приставов-исполнителей правонарушители уходят от ответственности, что может стимулировать банки к злоупотреблениям и необоснованному неисполнению требований исполнительных документов о взыскании денежных средств на счетах должников или об их аресте. ФССП РФ следует разработать подробные рекомендации по применению ч. 2 ст. 17.14 КоАП РФ, совершенствовать профессиональные навыки своих сотрудников в области административного законодательства.

Отчасти компенсировать низкую эффективность применения административной ответственности за неисполнение банком или иной кредитной организацией требований исполнительных документов о взыскании денежных средств должника или об их аресте может использование иных видов юридической ответственности. Так, например, на банк может быть наложен судебный штраф, предусмотренный ст. 119 АПК РФ и ст. 105 ГПК РФ ${ }^{16}$. Общество «Портал» 20 июля 2010 г. предъявило для исполнения в банк исполнительный лист от 5 мая 2010 г. серии АС № 001575516. Данный исполнительный документ возвращен банком без исполнения со ссылкой на то, что взыскателем к заявлению не был приложен оригинал доверенности на его представителя, и определение суда о процессуальном правопреемстве не вступило в силу. При повторном обращении взыскателя в банк, последний также возвратил исполнительный лист с указанием на различные наименования взыскателя в исполнительном документе и в поданном заявлении, что повлекло за собой обращение общества «Портал» в суд на бездействие банка, выразившееся в неисполнении требований, содержащихся в исполнительном листе от 5 мая 2010 г.

Оценив представленные сторонами доказательства с позиции ст. 71 АПК РФ, руководствуясь ст.ст. 48, 119, 187, 318, 319, 332 АПК РФ,

15 Постановление Девятого арбитражного апелляционного суда от 31 января 2012 г. по делу № А40111981/11-153-1013 // СПС КонсультантПлюс.

16 Гражданский процессуальный кодекс Российской Федерации от 14 ноября 2002 г. № 138-Ф3// Собрание законодательства РФ. 2002. № 46. Ст. 4532; Арбитражный процессуальный кодекс Российской Федерации от 24 июля 2002 г. № 95-Ф3 // Собрание законодательства РФ. 2002. № 30. СТ. 3012. 
ст. 7, 8, 70 Ф3 «Об исполнительном производстве», суды пришли к выводу о необходимости наложения на банк судебного штрафа в размеpe 25000 руб. за неисполнение им решения Арбитражного суда города Москвы от 29 января 2010 г., поскольку взыскателем в банк представлены все необходимые и предусмотренные действующим законодательством документы, которые должны были быть приняты банком к исполнению ${ }^{17}$.

Возможно также применение к банкамправонарушителям и гражданско-правовой ответственности, предусмотренной ст. 1064 ГК РФ в качестве компенсации за вред, при- чиненный личности или имуществу гражданина, а также вред, причиненный имуществу юридического лица.

Однако процессуальная и гражданско-правовая ответственность банков за неисполнение содержащегося в исполнительном документе требования о взыскании денежных средств с должника не столь эффективна, в отличие от административной. Речь, прежде всего, идет о размере штрафа или компенсации, к тому же суды довольно часто значительно снижают сумму компенсации. Поэтому необходимо совершенствовать практику применения за подобные правонарушения ч. 2 ст. 17.14 КоАП РФ.

Материал поступил в редакцию 08 августа 2013 г.

17 Определение ВАС РФ от 1 февраля 2012 г. № ВАС160/12 по делу № А40-122878/09-95-671// СПС Консуль- 